\title{
Issues on Religious Coexistence Tolerance in Albania (1912-1945)
}

\author{
Ahmed Kalaja \\ Ph.D. candidate, Europian University of Tirana, Department of Sociology, Tirana
}

\begin{abstract}
The religious tolerance is one of the rarest values of the tradition of the Albanian people. It is widely accepted that Albanian people are well known about these values, about an excellent coexistence among the believers of different religious communities that are in Albania, mainly Muslims and Christians.

In this study we bring the essentials of this phenomenon, promotional roots of these values, while viewed from a previously untreated point of view, and in an attempt to answer the questions: Where does it stem from the religious coexistence in Albania? What are the main promoters of this phenomenon? What has been the attitude of the religious clergy in Albania? Have they been and are the imams and priests, the promotion of tolerance and religious coexistence in Albania?

These are some of the questions answered in this modest study, focusing on how nice and with how much delicacy the lectures of the Clergy have addressed this issue to the faithful or to the world in general.

Since they enjoyed undisputable reputation and influence in the majority of the population, in the most critical moments of national history, the leaders of Muslims believers, not only have promoted tolerance and religious coexistence, but they have considered the believers of other faiths as "brothers" preaching this conviction in front of their Muslim believers. These preaching's were firstly begun by Vehbi Dibra, who was the first Chairman of the Muslims and all clerics without exception to this day.

Also unforgettable are the sermons of priests like: Fr. Gjergj Fishta, Fr. Shtjefën Gjeçovi, or Metropolitan Visarion Xhuvani to conclude with pearls of Orthodox priest, Fan S. Noli, who amazed the world with his three speeches in front of world leaders, the League of Nations, being representative of all Albanians, although Orthodox believers were only $20 \%$ of the population.
\end{abstract}

Key words: Tolerance, coexistence, clergy, nationalism, Albania

\section{THE FAITH}

Ordains to do good deeds firstly

Close neighbors, brothers, all Albanian sons,

Jewish, Christians, whatever they are

We must help them to love their country...

Hasan Selami
... Christians or Muslims whether, All they have Albania together,

So we all will stand and fight,

For Albania we will be a single unit, Priests, Friars, and Imams ...

Gjergj Fishta

\section{Introduction}

Tolerance and religious coexistence reigns for centuries among the Albanians as a value of the tradition of our country, which has constantly amazed foreigners, because they see it as a unique case this relationship of religious coexistence. This tradition is not of present day, neither it is a tradition of the past 100 years, but it is a tradition of several centuries, after Ottoman dominion in the Albanian land at the beginning of XVI century 
(years 1500). ${ }^{1}$. For this tradition and value they own Albanians are proud because it is one of the exclusive moments in the history of our country, for which all of us feel proud.

This fact has been proved even by foreign travellers who have visited our country at decisive moments, in moments when war was normality. One such case is offered by the British lady and admirer of Albanians Mrs. Edith Durham (at the beginning of $\mathrm{XX}^{\text {th }}$ century), who says: "Wars we have heard of between Albanians have always been of discords between rival Beys. Christians in this case have fought against Christians and Muslims against Muslims - in addition she states that- Muslim and Christian Albanians are brought together before their common enemy. ${ }^{2}$

This fact was noted from Albanians autonomy movements, where most of the founders were religious intellectuals, and a considerable part of them were clergymen of different faiths who led Albanians towards autonomy. Above all, even in the Declaration of Independence of Albania, on 28 November 1912 in Vlora, leading signatories were potent clergymen of all faiths. But the coexistence among believers of different faiths culminated in the Assembly of Vlora when it was decided that the Interim Government would have in its cabinet, members of four religious beliefs, regardless of the percentage of believers who had a religious community.

Even more the religious coexistence was very visible between Albanians in January 1920 when, in the Congress of Lushnja, Albania was declared a Constitutional Monarchy. The role of the Monarch had a High Council of Regency composed of four representatives of each faith.

In this material will be treated the concrete practice of clerical work on voice in the country, and their leadership, their lectures directed to the believers or speeches in special ceremonies cases.

\section{The Religion, Nationality and Nationalism}

There is no doubt that the faith is born together with the man. This is the reason why since the ancient times the people were grouped in tribes, which in general had a common religious origin, a common faith. During the ancient times, especially during the medieval times, the religion was an undisputable entity governing every aspect of people's lives, not only their spiritual life, but also material, political, economical and social life. Such a fact will be strongly opposed by the end of the Middle Ages and early modern times. Humanists and renaissance Greco-Roman traditions, would question undisputable 'authority' of the Church (in the west). Renaissance representatives' words will necessarily reason the 'Holy Bible' words, they questioned, reasoned them before applying. For them it wasn't true "what was descended by God", but the truth was what the human logic could understand, otherwise it wasn't valuable. They began to sanctify the life, the freedom of speech and the freedom of property. Indeed those were considered "sanctities" even before, but their sanctity was decided by God and not by the human reason. This "battle" was developed in Europe, because, in Islamic world, during the same period, a similar phenomenon couldn't exist, because in Islam, the political leader is necessarily and simultaneously responsible for the religion. It can't be perceived in Islam that the religion would be separate from the rest of the life, that's to say, the social, economical and political life of a country. To summon people towards an ideal that would substitute the position of religion, they found another common point of view, the nationality. By the term "nation" or "nationality" we understand a body of ethnic people which is formed historically during the decay of the tribe relationship sharing common language, territory and culture which is gradually developed and strengthened. ${ }^{3}$ This phenomenon that is known in Europe as "nationalism" =

\footnotetext{
${ }^{1}$ This is due to the fact that, during the medieval times, religious wars had ruling character of 'religious kings' and were part and parcel of the whole history of humanity, including here even our country till the establishment of Ottoman rule and the converting of the majority of the population in the Islamic religion.

${ }^{2}$ Edith Durham; Balkans' Concern, Tirana 1991.

${ }^{3}$ Group of authors; Dictionary of contemporary Albanian; first edition by the ACADEMY OF SCIENCE, Tirana 1984; TOENA, Tirana 2002,
} 
nationality" has its roots in France during the end of the XVII-th century and was spread in all Europe during the consequent centuries. The identification of the people with their "nationality" became a predominant phenomenon during the period of XIX - XX centuries, but the word "nationality" from the word "nation", have a very slight difference in meaning, but very essential one. We explained earlier the word "nationality" on what and how to understand, while with the word "nationalism" we understand: The ideology, or the point of view that a nation is superior to the other ones. ${ }^{4}$ These two terms almost equal have their common aspects, but they have essential differences in the aim of the term usage.

Apart from "joining" in their common positive aspects which caused the appearance of this new phenomenon, the "nationalism," brought about an even more harmful aspect, the separation with "neighbors", the separation with "others", who didn't have the same origin, language, culture, traditions as us, that's to say with "co-nationalists". So, this phenomenon, from a positive initiative, with the passing of time, turned into an initiative of problems in the following centuries in entire Europe.

Sometimes apart from the appearance of these terms, in all the world, the "nationality-nation" it wasn't seen as a common aspect between a certain group of people, but there were other aspects of life such as: the system of government, different interests, which were generally connected with the Religion or the Faith that each nation had. Whereas, after the period of Humanism and the Renaissance, this term was turned into a focal point for people of all Europe, used sometimes for good or for worse.

The nationalism, with its negative connotation, more than everywhere it was felt in Balkan. Exactly with "nationalism", but added to this the religion as a reinforcing factor, many nations were convinced to raise up against and not agree with the system of Great Empires, especially with Ottoman Empire. Joining these two elements, the peoples began the separation with "all" who were under the umbrella of the Empire and simultaneously were motivated to join around their "nationalism and religion", different from the "nationality and religion" of the Empire. Especially this phenomenon was urged in Balkans in order to stand up against the ottoman dominion, bringing about great benefits for some countries until they reached their independence such as: the Greeks, the Slavs, the Bulgarians, the Romanians, etc. and for several countries, which didn't have these common components, brought about grave problems which went far towards the risk of their complete disappearance. Concretely this happened to the Albanians, who were gathered around the "nationality", but they couldn't be unified with the religion, with a common faith, because they were multi- religious and couldn't change this reality.

In this manner, nationalism caused multidimensional disability in entire Balkans, as a result of which were the beginnings of the two World Wars. Consequently, this made the Balkans a field of battle towards themselves having "nationalism" as a starting point intertwined with the religion. Since 1830, time when the Greeks and the Serbians were separated from Ottoman Empire, gaining their independence, till the year 1912, time when Albania was declared independent the last state in the Balkans. After that, it was in the Balkans where started the First World War, even the Second World War. So, the Balkans, since the distant year 1821, till in the year 1999, only had simmered from many political, economical, and social wars, which were motivated by leaders nationally and religionly. We will focus more on the last point of these Independence "battles". "Nationalreligious" wars, done against the Ottoman Empire, which had a different faith from the traditional faith of people of the Balkans, were not considered sufficient, but religious 'wars' continued even within nation-states. These new battles were organized mainly against the Muslims, who were part of newly formed national states, due to the fact that from them was removed the age long Ottoman ruling. In this manner, as a sign of revenge, only

\footnotetext{
p. 594

${ }^{4}$ Group of authors; Dictionary of contemporary Albanian ; first edition by the ACADEMY OF SCIENCE , Tirana 1984; TOENA, Tirana 2002, p. 824
} 
about the fact that those people had the same faith as their "ottoman conqueror", they were discriminated, maltreated, ${ }^{5}$ were exiled from their land, ${ }^{6}$ and in some cases the war was used against them, even the genocide ${ }^{7}$

\section{The Clergy and the Declaration of Independence in Albania}

The declaration of Independence of our country is the greatest initiative of patriots and religious intellectuals, also one of the concrete deeds of the clergy towards the tolerance and religious coexistence settled as necessary criteria for the existence of this nation. We will mention here only some of the towns where the clergy were the initiator and signer of the Independence Act of their town. The clergy were present there and raised the flag of Independence of Albania.

To begin with town of Elbasan, which, in 25 November 1912, preceded the independence of other towns towards raising the Red and Black flag with the eagle. This act they would transfer to Vlora in the first hours of date 26, about 2 after midnight, in a telegram, where among others they announced that: "All our nation, Muslims and Christians, together with a voice have accepted the Independence of Albania..." One of the first signatories' of the Independence Act in Elbasan to be mentioned here: "Haxhi Hafiz Sulejman Kungulli, the vice of Mitrop. Pope Dhimitër Dhimitraku, Aqif Pashë Biçakçiu, Shefqet bej Vërlaci, Abdullah bej Tirana, the Mayor Alush Saraçi, Sheikh Mahmut Guma, Sheikh Xhafer Pasmaqja, Bishop Beniamin Deliana, Serafin Jorgaqi, Beniamin Nosi, Taq Buda, imam Hysein efendi Dorazi etc. etc."9

The same thing happened in Tirana and in Durrës, where the intelectuals and patriots led by the most important leaders of the city, in 26 November 1912, declared the Indipendence. Some of the first signatories of the Independence in the town of Durrës were: Myderiz (teacher) Abdylqerim Kurti, myderiz (teacher) Hysein Mulla-Alushi, myderiz Ali Kuli, myderiz (teacher) Hafidh Jusuf Gjoni, Ismail Benja, Mahmut Benja, Hysein Dakoli, Hasan Tartari, Ismail Usta Sula, Rexhep Abdurrahman Berberi, Hysein Peni, Filip Sereqi the leader of the Christian Catholics, Aqif Çelkupa, Aleks Duka, Kristaq Rama, Sotir Veveçka, Hamza Tahir Himi, Muhamet Qepaxhiu, Ymer Lutfi Mallkuçi, Musa Milaqi etc." ${ }^{10}$ While some of the signatories of Indipendence of Tirana were: Fuad bej Toptani, myderiz (teacher) Sulejmani, myderiz Hyseini, Xhelal bej Toptani, myderiz Ismail Ndroqi, Refik bej Toptani, Abdullah Gjinali, sheih Ahmet Pazari, Isuf Aqif Banka, Selim Petrela, Ali Shyqyri, Nikollë Nishku, Pope Nikollë Papajani...etc" $" 11$

The same thing happened in Kavaja, Peqin, Lushnja, where the Indipendence was declared the consequent day in 27 November 1912. In Kavaja signatories of Independence were: Qazim Fortuzi, Sheih Hamid Kraja, Mustë Cara, Andrea Ekonomi, Haxhi Isuf Kazazi, Pal Xhumari, Besim Sinella, Haxhi Xhoi, Zenel Biturku, Kostandin Qosja, Sali Kullolli, Hasan Nexha etc. ${ }^{12}$

\footnotetext{
${ }^{5}$ To be mentioned here almost similar situations with Muslims in Bulgaria, Montenegro, and even worse was their condition in Greece or Serbia. This phenomenon is widely known but is considered as a "national" problem, because the Muslims in these countries were called as "Turk's" in general, or Albanians in the case of Çamëria and so it was legalized the war against them. In some cases exchanges of the population were made, and in other cases the Muslims were exiled themselves in Ottoman Empire or new Turkey, whose foundations were laid after the First World War. For more information see: Alexandër POPOVIÇ "The Islamization of the Balkans”, Dituria publishing, Tirana 2006.

${ }^{6}$ Refer here especially the genocide against çameria population, as well as some Albanian towns in former Joguslavia.

${ }^{7}$ Elbasani Telegram 25/26 November 1912, FEVZIU, Blendi; 100 years in the politics of Albanian state from 1912-2012; UET-PRESS, Tirana 2012, p. 21

${ }^{8}$ KOTHERJA, Hyqmet; Elbasani Indipendence 1912; Dy Lindje Dy Perëndime publishing, Tiranë 2012, p. 7-9, also in NOSI, Lef; Doc. Nr. 2,

Historical Documents 1912-1920; Tirana 2007, p. 83

9 NOSI, Lef; Dok. Historical Documents 1912-1920 Tirana 2007 p.83

${ }^{10}$ NOSI, Lef; Dok. Historical Documents Nr.13300; 1912-1920; Tirana 2007, p. 81

${ }^{11}$ NOSI, Lef; Dok. Nr.2103 dhe 7098; Historical Documents 1912-1920; Tirana 2007, p. 82-83

${ }^{12}$ SHQARRI, Muharrem; The patriot, Shekh Hamid Kraja; OMBRA GVG, Tirana 2014, p. 85
} 
In Peqin signatories of Indipendence were: Kadri beu, son of Demir Pasha, Mufti Abdylbaki Biça, Sheikh Tahsin Gjinishi, Myderiz (Teacher) Sulejman Kuçi, The mayor Ahmet Kaziu, Asllan Ballhysa. ${ }^{13}$ The Christian element is missing in Peqin, because there were not Chritians in this town. In Lushnja the signatories were: Mufti sheikh Ibrahim Karbunara, myderiz (teacher) Sulejman Arapi, Kadri bej Karbunara, Emin bej Vokopola, Halid efendi Gramshi, Shaqir bej Lushja, Bishop Jovani, Sulejman Korreshi, Llambi Xoxi, Haxhi bej Imshta, Fejzullah bej Imshta, Thanas Paftali. ${ }^{14}$

To continue with the capital town of the Independence, in Vlora, where were gathered the most potent patriots and intellectuals and at the same time the leaders of clergy of this country. Some of the signatories of Independence in 28 November, 1912 in Vlora were: For Berat: Sami Vrioni, Ilias Vrioni, Taq Tutulani, Babë Dud Karbunara; For Skrapari: Xhelal Koprencka; Hajredin Cakrani; for Lushnja: Qemal Mullai, Ferit bej Vokopola, Nebi efendi Sefa; for Dibra: Myfti Vehbi Agolli-Dibra, Hafidh Sherif Lëngu (both of them were leaders of Albanian Muslim Community 1912-29 and 1942-45); for Mat: Ahmet Zogu, Riza bej Zogolli, Kurt Kadiu; for Ohri and Struga: Zyhdi Ohri, Dr. H. Myrtezai, Nuri Sojlli, Hamdi Ohri, Mustafa Baruti, Dervish Hima; for Durrës: Abaz efendi Çelkupa, Mustafa Agë Hanxhiu, Jahja Ballhysa, Dom Nikoll Kaçorri; for Tirana: Abdi Toptani, Murat Toptani; for Shijak: Xhelal Deliallisi, Ymer Deliallisi, Ibrahim Efendiu; for Kruja: Mustafa Merlika-Kruja; for Elbasan: Lef Nosi, Shefqet Daiu, Qemal Karaosmani, Dervish Biçaku; for Peqin: Mahmud efendi Kaziu; for Gramsh and Tomorrica: Ismail Qemal Gramshi; for Gjirokastra: Azis efendi Gjirokastra, Elmaz Boçe, Veli Harxhi, Myfid Libohova, Petro Poga, Jani Papadhopulli; for Përmet: Veli Këlcyra, Syrja Vlora; for Tepelena: Feim Mezhgorani; for Janina: Kristo Meksi, Aristidh Ruci; for Çamëria: Veli Gërra, Jakup Veseli, Rexhep Demi, Aziz Tahir Ajdonati; for Delvina: Avni Delvina; for Korça: Pandeli Cale, Thanas Floqi, Spiro Ilo; for Pogradec: Hajdar Blloshmi; for Kosovo, Gjakova, Plava-Gucia: Rexhep Mitrovica, Bedri Ipeku, Salih Gjuka, Mit'hat Frashëri, Mehmet Pashë Deralla, Isa Boletini, Riza Gjakova, Hajdin Draga, Dervish Ipeku, Zenel Begolli, Qerim Begolli; for Shkodra: Luigj Gurakuqi; and representatives for Vlora were: Ismail Qemali, Zihni Abaz Kanina, Aristidh Ruci, Qazim Kokoshi, Jani Minga, Eqrem Bej Vlora; and abroad: Dhimitër Zografi, Dhimitër Mborja, Dhimitër Berati, Dhimitër Ilo, etc. etc. ${ }^{15}$

Almost all these personalities, signatories of the Act of Independence, were believers, for the simple reason that they had minimally the primary and higher education about religion. Some of them had their degrees in theology, and also were clerics of their respective towns and had undisputable reputation in Albanian population during the years 1912-1920. Some of them were myderiz =religion teachers, some others imams, priests or dervishs, who led their cult institutions of their towns. While others were in the role of Mufti, Metropolitan or vice Metropolitan, some were bishops and so on, but some of the clergy were mayors of their respective municipalities, which meant a greater risk for them. So, in conlusion, we can say that the representatives of the population in Assembly of Vlora in 1912 were Muslims and Christians, and a considerable number of them were Clergy, some of them we can mention here: Mufti Vehbi Efendi Agolli, Hafidh Sherif Langu, Babë Dud (Jorgji) Karbunara, Taq (Dhimitër) Tutulani, Father Nikoll Kaçorri etc. Ismail (Qemal) Vlora in his "Memories" describes as historical and very important the Act of Indipendence. He writes: National Assembly, composed of delegates from all the regions of Albania, regardless of religion gathered here in (28.11.1912) in Vlora, declared the political Independence of Albania... 16

The coexistence between clergy and the believers of different faiths, culminated in the Assembly of Vlora, where it was decided that the Government of Ismail Qemali will have in its cabinet representatives of the four faiths, regardless of the percentage of each community of believers. It must be poitned out that Ismail Qemali in choosing members of the Government from his part had included 8 personalities with reputation, who were

\footnotetext{
${ }^{13}$ NOSI, Lef; Dok. Nr. 1146; Historical Documents 1912-1920; Tirana 2007, p. 89

${ }^{14}$ GRIPSHI, Genc; The History of Peqin; Reklama, Tirana, 2014, p. 141

${ }_{15}^{15}$ FRASHËRI, Kristo; The Declaration of Independence of Albania 28 November 1912; The Academy of Sciences, Tirana 2008, p. 91-94

${ }^{16}$ QEMALI, Ismail; Memories; Toena, Tirana 2009, p. 418
} 
seen as more effective for a longevity of the Government, until the situation would be normalized. This cabinet proposed by Ismail Vlora did not found the approval of the audience because it comprised members from the Muslim community (Sunni and bektashi sect) and none from the Chritians. Bab Dud Karbunara was the first to refuse this choice proposing that the Government should have Muslims and Christians in its composition and to protect the integrity of each one, the proposed members should be chosen with vote by the participants. ${ }^{17}$

In order to realize this, the Parliament had a very important duty to accomplish: voting the Cabinet of the Provisional Government, showing by this act an excellent tolerance and simultaneously a democratic act, because in each ministerial post was elected the person who gained more votes regardless of his faith. In this way, the Provisional Government of Vlora was formed based on the religious affiliation of the country, with the proposal of Bab Dud Karbunara. Muslims and Christians should participate in it, and each minister would be elected after he would take the majority of the votes of present participants. Vlora Government eventually had the following composition: Prime minister of the Government and Minister of Foreign Affairs, Ismail Qemal Vlora; Vice Prime minister of the Government, Dom Nikollë Kacorri; (12/25/1912) Preng Bibë Doda; Minister of Education, Luigj Gurakuqi; Minister of Interior, Myfit Libohova; Finance Minister, Abdi Toptani; Minister of War, Mehmet Pashë Dëralla (Tetova); Minister of Justice Petro Poga; Minister of public works, Mit'hat Frashëri; Agriculture Minister Pandeli Cale; Minister of Posts and Telegraph, Lef Nosi

After this the Parliament had another duty, the selection of the Elderly Commission, comprised of 18 persons. On the proposal of Ismail (Qemal) Vlora was decided that the Elderly Commission would be the "vicegerent" of the Parliament, would have the role of advisor, auditorial and collaborator with the Government, but in no way to ever throw it. ${ }^{18}$ With the proposal of Luigj Gurakuqi, Vehbi Dibra was elected the Head of the Elderly Commission (the Senate) and vice president was elected Lef Nosi, a representative of another religious origin. ${ }^{19}$ Simultaneously, Vehbi Dibra exerted the duty of substitute/vice for Ismail Qemali when he was abroad. The Elderly Commission under the direction of honored Mufti Vehbi Dibra, took many important decisions, being a perfect example of democracy, and religious tolerance.

The initiative of "tolerance and religious coexistence" was firstly taken by the Leader of the Muslim Community, Haxhi Vehbi Dibra, who gave the Fatwa (religiously legalized) of the Independence of Albania. In fact, his fatwa was about legitimizing the Flag with its eagle as a symbol, because that was no accepted by some muftis in the country and even it was not accepted by the people in general. It was not easy for a people who coexisted with ottomans under the great umbrella of the Empire, that in such a delicate moment to accept the division from the Empire. To reason this, Haxhi Vehbi Dibra, in the role of Headmufti of our country, gave the fatwa, where among others he stated: “...in order to preserve the unity of people and to banish the disputes and the anger, and in order to ensure a general peace, the symbol of eagle must be protected. This fetwa is based on Shariah and on the need of the time and place..." ${ }^{20}$ Vehbi Dibra did not confine himself with the fetwa to consider this problem solved, but Ismail Qemali left him full competences to solve this problem as he thought it reasonable, on its roots. So Haxhi Vehbi Dibra travelled in some towns of the country talking with the muftis and with the believers, which comprised the majority of the population, and in this way the situation was tranquilized. ${ }^{21}$ With his acts and wise words, Haxhi Vehbi Dibra, in a certain way addressed the Muslim Albanians that their fate was not any more under the Empire, which seemed to dawn, but, on the other hand, they would be united towards the "nationality", despite the religious origin. The goal of this outstanding patriot was

\footnotetext{
${ }^{17}$ For more information: The Renaissance of Albania, 1913 - 1914, Official newspaper Government of Vlora

${ }^{18}$ XHELILI, Qazim; Vehbi Dibra - personality and well known activist of the national movement; Albin, Tirana, 1998 , p. 96

${ }^{19}$ XHELILI, Qazim; Vehbi Dibra - personality and well known activist of the national movement ; Albin, Tirana, 1998 , p. 96

${ }^{20}$ A.Q.SH. Fund The Caretaker Government of Vlora, Folder III, 5/2, page 632

${ }^{21}$ XHELILI, Qazim; Vehbi Dibra - personality and well known activist of the national movement; Albin, Tirana; $1998, \mathrm{p} .106$
} 
unity and brotherhood. He said that: "Our country needs the national unity and brotherhood despite the religious origin." 22

\section{References}

\section{Archive sources}

${ }^{[1]}$ A.Q.SH. Fund 482, Folder, 14, year 1925, p. 191

${ }^{[2]}$ A.Q.SH. Fund Qeverisë së Përkohshme e Vlorës, Folder III, 5/2, p 632

\section{Studies \& Books}

${ }^{[3]}$ Dervishi, Kastriot; The History of Albanian State 1912-2005; Publishing House 55, Tirana 2006

${ }^{[4]}$ Dibra, Haxhi Vehbi; What Koran orders; Albanian Muslim Community, Tirana 2014

${ }^{[5]}$ Duka, Ferit; "The Historical background of religious tolerance in Albania", International Symposium: "Perspectives of religious, cultural and social diversity, in Balkans seen from a Global Perspective", 25-26 March 2011 organised in Tirana; PRIZMI publications, Tirana 2012

${ }^{[6]}$ Durham , Edith; Balkan's Concerns; Tirana 1991.

${ }^{[7]}$ Fevziu, Blendi; 100 years - An excursion in politics of Albanian state from 1912-2012; UET-PRESS, Tirana 2012

${ }^{[8]}$ Fishta, Gjergj; Lahuta e Malcis; Uegen, Tirana 2010

${ }^{[9]}$ Frashëri, Kristo; The declaration of Indipendence of Albania 28 nëntor 1912; Science Academy, Tirana 2008

${ }^{[10]}$ Group of authors; ENCYCLOPAEDIA - 100 Albanian Personalities from Islamic Culture during cent. XIX - XX; KMSH, Tirana 2012

${ }^{[11]}$ Group of authors ; Dictionary of Contemporary Albanian; first edition by Science Academy, Tirana 1984; second edition by Toena, Tirana 2002

${ }^{[12]}$ Group of authors ; The History of Albanian People III (Renaissance Period 1912-1939); Toena, Tirana 2007

${ }^{[13]}$ Gripshi, Genc; History of Peqin; Reklama, Tirana, 2014,

${ }^{[14]}$ Kraja, Hafiz Ali; Religion - Is it necessary, Does it hampers national unity?; first edition in 1934; Albanian Muslim Comm, Tirana 2010

${ }^{[15]}$ Kotherja, Hyqmet; The Renaissance of Elbasan 1912; Dy Lindje Dy Perëndime, Tirana 2012

${ }^{[16]}$ Mata, Ruxhdi; Father Shtjefën Gjeçovi, His Life and Deeds; SHBLSH, Tirana 1982

${ }^{[17]}$ Merdani; Arlinda; Interreligious relationships in Albania, New Prespectives for the Europian Union; ONUFRI, Tirana 2014

${ }^{[18]}$ Noli, Fan S.; Speeches (1906 - 1964); prepared by Nasho Jorgaqi; DUDAJ, Tirana 2002

${ }^{[19]}$ Nosi, Lef; Doc. Nr. 2, Historical Documents 1912-1920; Tirana 2007

${ }^{[20]}$ Popoviç, Alexandër; Balkans Islamization; Dituria, Tirana 2006

${ }^{[21]}$ Qemali, Ismail; Memorie; Toena, Tirana 2009

${ }^{[22]}$ Shqarri, Muharrem; The Patriot Sheh Hamid Kraja; OMBRA GVG, Tirana 2014, p. 85

${ }^{[23]}$ Xhelili, Qazim; Vehbi Dibra - personality and wellknown activist of national movement; Albin, Tirana, 1998

\section{Newspapers and Magazines}

${ }^{[24]}$ Kultura Islame; year 1944, "Tirana", Tirana 1942

${ }^{[25]}$ Kultura Islame; year 1942, "Tirana”, Tirana 1944

${ }^{[26]}$ Përlindja e Shqipëniës; Vlora 1913

${ }^{[27]}$ Përlindja e Shqipëniës; Vlora 1914

${ }^{[28]}$ Udha e s'Vërtetës; viti parë, $n r$. 2, "Ora” Shkodra, October 1923

${ }^{[29]}$ Zani i Naltë; year 1923, "Mbrothwsia", Tirana 1923

${ }^{[30]}$ Zani i Naltë; year 1927, "Ora”, Shkodra 1927

${ }^{[31]}$ Zani i Naltë; year 1928, "Ora”, Shkodra 1928

${ }^{[32]}$ Zani i Naltë; year 1932, "Ora”, Shkodra 1932

${ }^{[33]}$ Zani i Naltë; year 1935, "Ora”, Shkodra 1935

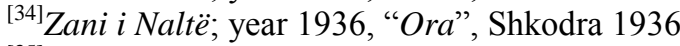

${ }^{[35]}$ Zani i Naltë; year 1938, "Ora”, Shkodra 1938

${ }^{22}$ A.Q.SH. Fund 482, Folder, 14, year 1925, p. 191 